\title{
Estimated dry biomass for summer crops in the subtropical zone in Southern Brazil
}

\author{
Biomasa seca estimada para cultivos de verano \\ en la zona subtropical del sur de Brasil
}

\author{
Jorge Luiz Moretti de Souza1, Felipe Augusto Piacentini Grabarski ${ }^{1}$, \\ Aline Aparecida dos Santos ${ }^{1}$, Stefanie Lais Kreutz Rosa ${ }^{1 *}$, Volnei Pauletti ${ }^{1}$
}

\begin{abstract}
The objective of this study was to calibrate and validate models to estimate dry biomass of maize and soybean crops in the Campos Gerais region, located in the subtropical zone in southern Brazil, with incident solar radiation (Rs), growing degree days (GDD), days after planting (DAP) and precipitation (P) as variables. The experiments were carried out in the 2006/2007 and 2007/2008 harvests in Castro and Ponta Grossa cities, in four phenological stages, to obtain dry biomass. The climate data came from the ABC Foundation agrometeorological stations, installed close to the experimental areas. The parameters adjustment was performed by the Least Squares Method and using a spreadsheet Solver. The soybean harvests with the highest DAP, Rs, and P until physiological maturation were not the ones that obtained the highest final dry biomass productivity, except for the GDD variable. As sowing was performed later, the soybean crop cycle decreased. With the exception of the models' performance for the precipitation variable (between "Terrible" and "Excellent") for soybean and maize crops, the other variables presented promising performances between "Bad" and "Excellent", with a predominance of "Excellent".
\end{abstract}

Keywords: agricultural production, growth models, performance.

\section{RESUMEN}

El objetivo de este estudio fue calibrar y validar modelos para estimar la biomasa seca de cultivos de maíz y soja en la región de Campos Gerais, ubicada en la zona subtropical del sur de Brasil, con las variables radiación solar incidente (Rs), grados días como acumulado (GDA), días después de la siembra (DAP) y precipitación $(P)$. Los experimentos se realizaron en las cosechas 2006/2007 y 2007/2008, en los municipios de Castro y Ponta Grossa, en cuatro etapas fenológicas, para obtener biomasa seca. Los datos climáticos son de las estaciones agrometeorológicas de la Fundación ABC, instaladas cerca de las áreas experimentales. Los parámetros se ajustaron mediante el método de mínimos cuadrados y la herramienta Solver de una hoja electrónica de cálculo electrónica. Los cultivos de soja que presentaron mayor DAP, Rs y P hasta alcanzar la etapa de maduración fisiológica no fueron los que obtuvieron mayor productividad final de biomasa seca, a excepción de la variable GDA. Como la siembra se llevó a cabo tardíamente, el ciclo de la soja disminuyó. Con excepción del desempeño de los modelos de precipitación (entre "Terrible" y "Excelente") para soja y maíz, las otras variables mostraron comportamientos prometedores entre "Malo" y "Excelente", con predominio de "Excelente".

Palabras clave: producción agrícola, modelos de crecimiento, desempeño.

\section{Introduction}

The dry biomass of crops is an important source of renewable energy, mainly thermal and electrical. The Campos Gerais region, in Paraná State, stands out for its high agricultural production, such as grain production in the summer, mainly maize and soybean crops.

Maize and soybean crops produce large amounts of residual biomass, which can be used both for a no-tillage system and energy production through direct straw combustion (Xu et al., 2020).

\footnotetext{
1 Federal University of Paraná, Department of Soils and Agricultural Engineering. Curitiba, Paraná, Brazil.

* Corresponding author: skreutzrosa@gmail.com
}

Fecha de Recepción: 17 de Diciembre, 2020.

Fecha de Aceptación: 31 de Mayo, 2021. 
Even though there are doubts about removing soil cover for energy generation (Moebius-Clune et al., 2008), the partial removal of biomass has irrelevant effects concerning the maintenance of organic matter content and soil conservation.

The maximum crop potential productive is reached if some factors follow the crop requirements. In addition to the nutrients and pests management, aspects such as temperature, precipitation, and solar radiation, must meet the crop requirements. Incident solar radiation (Rs) is the main energy source of in the environment, fundamental for the photosynthesis and plant development, and is vital in several areas (Chukwujindu, 2017). Understanding the relationships between solar radiation, temperature, and water in the soil are essential to obtain great quality and crop productivity (Palencia et al., 2013).

Agricultural planning is the best option to achieve the genetic potential of crops for maximum biomass production. The use of mathematical models and functions is an excellent alternative to estimate plant production, enabling the assessment of plant growth dynamics and final plant growth. Therefore, it is essential to study agricultural systems using models and data that characterize how a given system behaves in specific circumstances. The models allow the use of computational tools that help to identify the best options and the associated risks (Jones et al., 2017).

Given the context presented, the objective of this study was to calibrate and validate recommended models to estimate dry biomass of maize and soybean crops in the Campos Gerais region, located in the subtropical zone in southern Brazil, with incident solar radiation (Rs), growing degree days (GDD), days after planting (DAP) and precipitation (P) as variables.

\section{Material and Methods}

The study area is located in the Campos Gerais region, Paraná State, in two localities: i) Ponta Grossa, with an Oxisol, sandy clay texture, gently undulating relief and humid subtropical climate (Cfb); and ii) Castro, with an Oxisol, clay texture, 9.6\% slope and humid subtropical climate (Cfb) (Álvares et al., 2013). Ponta Grossa and Castro have an average temperature of $17.5^{\circ} \mathrm{C}$ and $16.9^{\circ} \mathrm{C}$ and precipitation of $1495 \mathrm{~mm}$ year ${ }^{-1}$ and $1553 \mathrm{~mm}$ year ${ }^{-1}$, respectively.

The dry biomass and climatic data for soybean and maize crops were provided from experiments carried out in experimental stations from $A B C$ Foundation Agricultural Research and Development, at 2006/2007 and 2007/2008 harvests. For each crop, four experimental areas were installed.

The cultivars used, sowing dates, and locations of each harvest are shown in Table 1. In the experimental areas, four samples of whole plants were collected for aerial biomass determination in the following phenological growth stages: four fully expanded leaf (V4), eight fully expanded leaf (V8), full flowering (FF), and physiological maturity (PM). For all crops, plants were collected approximately $0.01 \mathrm{~m}$ from the soil surface.

At the last stage, the plants were collected and divided into grains and aerial biomass. After separation, the plants were weighed in the field to quantify the fresh biomass. All the collected and weighed material was sent to the laboratory for drying in an oven at $70{ }^{\circ} \mathrm{C}$ until constant weight, for dry biomass quantification, for the first two phenological stages (V4 and V8). For the final two stages (FF and PM), due to the volume of material collected, a sample of whole plants weighed fresh

Table 1. Cultivars, localitie, harvest and sowing date of maize and soybean crops, in Campos Gerais, Southern Brazil.

\begin{tabular}{lllll}
\hline Crop & Cultivar & \multicolumn{1}{c}{ Localitie } & Harvest & \multicolumn{1}{c}{ Sowing date } \\
\hline \multirow{4}{*}{ Maize } & P 30F53 & Castro & 2006/2007 & September 28, 2006 \\
& P 30F53 & Castro & 2007/2008a & October 4, 2007 \\
& P 30F53 & Castro & 2007/2008b & October 10, 2007 \\
& P 30F53 & Ponta Grossa & $2007 / 2008$ & October 3, 2007 \\
\hline \multirow{5}{*}{ Soybean } & CD 206 & Castro & $2006 / 2007$ & November 15, 2006 \\
& CD 206 & Ponta Grossa & $2006 / 2007$ & November 27, 2006 \\
& CD 206 & Castro & $2007 / 2008$ & November 7, 2007 \\
& CD 206 & Ponta Grossa & $2007 / 2008$ & October 17, 2007 \\
\hline
\end{tabular}


was separated and sent to the laboratory for drying. The dry biomass per hectare was calculated with the collection area's total fresh biomass data and the sample moisture values.

The parameters of Streibig (1988), Gompertz and Philos (1825), Ratkowsky (1983), Brody (1945), Bertalanffy (1957), and García y García (2002) models were adjusted by the Least Squares Method and using a spreadsheet Solver. The calibration was performed with three harvests from different locations and years. Subsequently, each model was validated with harvests not used in the calibration. The models consider the input variables: days after planting (DAP), accumulated growing degree days (GDD), accumulated incident solar radiation (Rs), and accumulated precipitation $(\mathrm{P})$.

Non-linear logistic model, proposed by Streibig (1988):

$$
y\left(x_{i}\right)=\frac{a}{\left[1+\left(\frac{x_{i}}{c}\right)^{b}\right]}
$$

Non-linear model, proposed by Gompertz and Philos (1825):

$$
y\left(x_{i}\right)=a \cdot \exp \left[-b \cdot \exp \left(-c \cdot x_{i}\right)\right]
$$

Non-linear model, proposed by Ratkowsky (1983):

$$
y\left(x_{i}\right)=\frac{a}{1+b \cdot e^{\left(-c \cdot x_{i}\right)}}
$$

Non-linear model, proposed by Brody (1945).

$$
y\left(x_{i}\right)=a \cdot\left[1-b \cdot e^{\left(-c \cdot x_{i}\right)}\right]
$$

Non-linear model, proposed by Bertalanffy (1957):

$$
y\left(x_{i}\right)=a \cdot\left[1-b \cdot e^{\left(-c \cdot x_{i}\right)}\right]^{3}
$$

Sigmoidal model, proposed by García y García (2002):

$$
y\left(x_{i}\right)=a \cdot\left\{\frac{1}{2} \cdot\left[\operatorname{sen}\left(\frac{3 \cdot \pi}{2}+\pi \cdot \frac{x_{i}}{c}\right)+1\right]\right\}^{b}
$$

Where: $\mathrm{y}\left(\mathrm{x}_{\mathrm{i}}\right)$ - total dry biomass as a function of variable $\mathrm{x}\left(\mathrm{kg} \mathrm{ha}^{-1}\right) ; \mathrm{x}_{\mathrm{i}}-$ an independent variable value, evaluated at each i-days after planting (DAP; day), accumulated degree days until each i-day $\left(\mathrm{GDD}_{\mathrm{i}} ;{ }^{\circ} \mathrm{C}\right)$, incident solar radiation accumulated until the each i-day $\left(\mathrm{Rs}_{\mathrm{i}} ; \mathrm{MJ} \mathrm{m}^{-2} \mathrm{day}^{-1}\right)$ and accumulated precipitation up to each i-day $\left(\mathrm{P}_{\mathrm{i}}\right.$; mm day $\left.{ }^{-1}\right)$; "a," "b" and "c" - parameters of the equation (a: $\mathrm{kg} \mathrm{ha}^{-1}$; b: dimensionless; c: Eq. (1) and Eq. (6) have the same unit as the independent variable, and Eq. (2) to Eq. (5) have the inverse of the same unit as the independent variable).

The accumulated degree days were calculated with the sum of:

$$
\mathrm{ADD}_{\mathrm{i}}=\sum_{\mathrm{i}=1}^{\mathrm{n}} \mathrm{DD}_{\mathrm{i}}
$$

Where: $\mathrm{ADD}_{\mathrm{i}}$ - accumulated degree days at each i-day $\left({ }^{\circ} \mathrm{C}\right) ; \mathrm{DD}_{\mathrm{i}}$ - degree days at each i-day.

The degree days were calculated using the method proposed by Arnold (1959), which considers only the lower basal temperature $\left(\mathrm{T}_{\text {basal }}\right)$ when calculating the degree-days:

$$
\mathrm{DD}_{\mathrm{i}}=\frac{(\mathrm{T} \max +\mathrm{T} \min )}{2}-\mathrm{T}_{\text {basal }}
$$

Where: $\mathrm{DD}_{\mathrm{i}}-$ degree days at each i-day $\left({ }^{\circ} \mathrm{C}\right)$; $\mathrm{Tmax}_{\mathrm{i}}-$ maximum temperature recorded at each i-day $\left({ }^{\circ} \mathrm{C}\right) ; \operatorname{Tmin}_{\mathrm{i}}-$ minimum temperature recorded at each i-day $\left({ }^{\circ} \mathrm{C}\right) ; \mathrm{T}_{\text {basal }}$ - lower basal temperature of the crop $\left({ }^{\circ} \mathrm{C}\right)$.

The minimum temperatures required for the development of maize and soybean crops were considered to be $10{ }^{\circ} \mathrm{C}$ (Sánchez et al., 2014) and $13{ }^{\circ} \mathrm{C}$ (INMET, 2009), respectively.

The associations between observed (in the field; $\mathrm{kg} \mathrm{ha}^{-1}$ ) and estimated (with models; $\mathrm{kg} \mathrm{ha}^{-1}$ ) biomass values were verified in simple linear regression analyzes. For comparison, absolute (AE) and relative (RE) errors, Pearson correlation coefficient (r), indexes of agreement "d" and performance "c" were calculated (Souza, 2018). The "c" index values $(c=r . d)$ indicate the following performance of the tested model: "Excellent" ("c" $>0,85)$; "Very good" $(0,76 \leq$ "c" $\leq 0,85)$; "Good" $(0,66 \leq$ "c" $\leq 0,75)$; "Medium" $(0,61 \leq$ "c" $\leq 0,65)$; "Tolerable" $(0,51 \leq$ "c" $\leq 0,60)$; "Bad" $(0,41 \leq$ "c" $\leq 0,50$ ); and, "Terrible" ("c" $\leq 0,40$ ).

\section{Results and Discussion}

For soybean crops, the harvest that had the most porlonged period of days after planting, 
incident solar radiation, and precipitation to reach the physiological maturation stage were not the ones that obtained the highest final dry biomass productivity (Table 2). The same did not occur with the accumulated degree days (GDA).

At the V4 phenological stage, the highest biomass productivity occurred in the "Ponta Grossa 2006/2007" harvest for soybean, and the harvest presented: fewer days after planting to change the stage (29 days); lower accumulated incident solar radiation (608.40 $\mathrm{MJ} \mathrm{m}^{-2}$ day $\left.^{-1}\right)$; less accumulated precipitation $(96.20 \mathrm{~mm})$; and, the second-lowest accumulated degree days $\left(292.75^{\circ} \mathrm{C}\right)$. At the V8 soybean stage, there were the same characteristics observed at the V4. Except for the accumulated degree days (GDD), the exact characteristics of the variables were observed in the full flowering stage (FF), in which the "Ponta Grossa 2006/2007" harvest showed the lowest variable value. At this same stage and harvest, the value of dry biomass was the second-lowest concerning other crops. In the physiological maturation stage (PM), the highest values of all variables observed in the soybean harvest (Ponta Grossa 2007/2008) occurred and, consequently, the highest productivity of dry biomass. In the "Ponta Grossa 2006/2007" soybean harvest, the second-highest dry biomass yield was obtained, and the physiological maturation stage (PM) occurred in a shorter period. The same stage and harvest showed the second-highest value of accumulated degree days $\left(1294.30^{\circ} \mathrm{C}\right)$ between harvests.

Except for "Castro 2007/2008" harvest, the accumulated degree days (GDD) to reach physiological maturation were higher than those found in the literature. Wazilewski et al. (2011) observed $1130{ }^{\circ} \mathrm{C}$ of accumulated degree days to reach the physiological maturation stage in a research carried out with soybeans in Cascavel city, Paraná State. Souza et al. (2010) observed a complete phenological cycle with $1200{ }^{\circ} \mathrm{C}$ of accumulated degree days evaluating an early soybean cultivar in northeastern Pará State.

At the V8 stage (Table 2) in the "Castro 2006/2007 and 2007/2008" soybean harvests, the days after planting were the same, and the accumulated incident solar radiation in the period was similar. However, the accumulated degree days were higher in the "Castro 2006/2007" harvest than the precipitation, which was higher in the "Castro 2007/2008" harvest. The "Castro 2006/2007" considering the dry biomass productivity at the V8 stage harvest presented $311.27 \mathrm{~kg} \mathrm{ha}^{-1}$ more than the "Castro 2007/2008" harvest (Table 2). The result indicated that higher temperatures in certain phenological stages are more influential in the plants' biomass accumulation than the incident solar radiation.

The "Castro 2007/2008a" and "Ponta Grossa 2007/2008" maize harvests were the ones that had the longest time to reach physiological maturation, being 174 and 175 days after planting, respectively. Even with a difference of only one day, it was observed that the accumulated degree days, accumulated incident solar radiation, and accumulated precipitation were relatively higher in the "Ponta Grossa 2007/2008" harvest. The final dry biomass yield between harvests was also higher, with both surpassing the others (Table 2). At the full flowering stage, the "Castro 2007/2008b" and "Ponta Grossa 2007/2008" harvests presented the same days after planting (85 days). However, in the "Ponta Grossa 2007/2008" harvest, there was an increase of $78.6^{\circ} \mathrm{C}$ of accumulated degree days, accumulated incident solar radiation of $169.6 \mathrm{MJ}$ $\mathrm{m}^{-2}$ day $^{-1}$, and a precipitation decrease of $88.7 \mathrm{~mm}$ compared to "Castro 2007/2008b" harvest. The "Castro 2007/2008b" harvest presented a reduction of $1164.74 \mathrm{~kg} \mathrm{ha}^{-1}$ in biomass productivity concerning the "Ponta Grossa 2007/2008" harvest, showing the influence of variables on dry biomass productivity.

Even adjusted, the "a" parameters values were similar to dry biomass yield in the final stage of each crop season (Table 3). Each model parameters values were close between harvests, except for "a" parameter in the Brody model. The results obtained are consistent since most of the studied functions are exponential models, in which the "a" parameter represents the maximum value obtained by variable (mass, size, volume, among others) in the considered cycle.

For some variables, the " $\mathrm{b}$ " parameter values were close in all soybean crops (Table 3 ). In the Streibig model, "b" parameters varied between -6.32 and -4.79 for days after planting (DAP), accumulated degree days (GDD), and accumulated incident solar radiation (Rs). For the accumulated precipitation $(\mathrm{P})$, there was a higher variation of " $\mathrm{b}$ " ( -9.06 to -3.50$)$. The same occurred in Gompertz and Philos, Brody, Bertalanffy, and García y García models, in which the accumulated precipitation (P) in the "Castro 2007/2008" soybean harvest 
Table 2. Real dry biomass, days after planting, degree days after planting and accumulated incident solar radiation and precipitation at the end of each soybean and maize crops phenological stage, for different harvests, in Campos Gerais, Southern Brazil.

\begin{tabular}{|c|c|c|c|c|c|}
\hline \multirow{2}{*}{ Variable } & \multirow{2}{*}{ Harvest } & \multicolumn{4}{|c|}{ Phenological stage } \\
\hline & & V4 & V8 & $\mathrm{FF}$ & $\mathrm{PM}$ \\
\hline \multicolumn{6}{|c|}{ Soybean } \\
\hline \multirow{4}{*}{ Real dry biomass $\left(\mathrm{kg} \mathrm{ha}^{-1}\right)$} & C-2006/2007(1) & 382.69 & 1432.33 & 3897.71 & 7959.83 \\
\hline & P-2006/2007(2) & 930.13 & 1642.96 & 4805.79 & 8661.25 \\
\hline & C-2007/2008(1) & 347.21 & 1121.06 & 5410.13 & 7366.71 \\
\hline & P-2007/2008(2) & 373.31 & 715.44 & 6172.17 & 12771.25 \\
\hline \multirow{4}{*}{ Days after planting (day) } & C-2006/2007(1) & 37.00 & 51.00 & 68.00 & 134.00 \\
\hline & P-2006/2007(2) & 29.00 & 43.00 & 56.00 & 127.00 \\
\hline & C-2007/2008(1) & 36.00 & 51.00 & 82.00 & 149.00 \\
\hline & P-2007/2008 (2) & 41.00 & 56.00 & 85.00 & 161.00 \\
\hline \multirow{4}{*}{ Degree days after planting $\left({ }^{\circ} \mathrm{C}\right)$} & C-2006/2007(1) & 337.95 & 468.05 & 618.80 & 1225.20 \\
\hline & P-2006/2007(2) & 292.75 & 431.50 & 563.00 & 1294.30 \\
\hline & C-2007/2008(1) & 266.35 & 374.75 & 607.75 & 1104.30 \\
\hline & P-2007/2008(2) & 330.05 & 473.35 & 735.45 & 1358.85 \\
\hline \multirow{4}{*}{ Accumulated incident solar radiation $\left(\mathrm{MJ} \mathrm{m}^{-2}\right.$ day $\left.^{-1}\right)$} & C-2006/2007(1) & 790.90 & 1056.00 & 1419.50 & 2765.90 \\
\hline & P-2006/2007(2) & 608.40 & 881.10 & 1174.30 & 2613.40 \\
\hline & C-2007/2008(1) & 722.30 & 1059.40 & 1610.40 & 2717.00 \\
\hline & P-2007/2008(2) & 812.50 & 1141.30 & 1830.90 & 3262.30 \\
\hline \multirow{4}{*}{ Accumulated precipitation (mm) } & C-2006/2007(1) & 163.00 & 246.30 & 345.10 & 627.80 \\
\hline & P-2006/2007(2) & 96.20 & 131.80 & 201.20 & 490.80 \\
\hline & C-2007/2008(1) & 280.10 & 328.00 & 441.40 & 668.70 \\
\hline & P-2007/2008 (2) & 160.40 & 263.40 & 428.60 & 735.20 \\
\hline & Maize & & & & \\
\hline \multirow{4}{*}{ Real dry biomass $\left(\mathrm{kg} \mathrm{ha}^{-1}\right)$} & C-2006/2007(1) & 534.40 & 1019.79 & 4860.52 & 3072.22 \\
\hline & C-2007/2008 $a^{(1)}$ & 110.92 & 4332.07 & 9917.79 & 17629.99 \\
\hline & $C-2007 / 2008 b^{(1)}$ & 279.02 & 3423.98 & 9034.99 & 14259.64 \\
\hline & P-2007/2008(2) & 1176.99 & 3307.44 & 10199.73 & 20677.49 \\
\hline \multirow{4}{*}{ Days after planting (day) } & C-2006/2007(1) & 39.00 & 68.00 & 85.00 & 146.00 \\
\hline & $C-2007 / 2008 a^{(1)}$ & 46.00 & 77.00 & 97.00 & 174.00 \\
\hline & $C-2007 / 2008 b^{(1)}$ & 35.00 & 64.00 & 85.00 & 160.00 \\
\hline & P-2007/2008(2) & 48.00 & 61.00 & 85.00 & 175.00 \\
\hline \multirow{4}{*}{ Degree days after planting $\left({ }^{\circ} \mathrm{C}\right)$} & C-2006/2007(1) & 374.10 & 671.95 & 878.75 & 1612.40 \\
\hline & $C-2007 / 2008 a^{(1)}$ & 481.75 & 801.55 & 1028.85 & 1834.95 \\
\hline & $C-2007 / 2008 b^{(1)}$ & 377.55 & 674.80 & 899.70 & 1696.05 \\
\hline & P-2007/2008 (2) & 549.80 & 698.80 & 978.30 & 2011.25 \\
\hline \multirow{4}{*}{ Accumulated incident solar radiation $\left(\mathrm{MJ} \mathrm{m}^{-2} \mathrm{day}^{-1}\right)$} & C-2006/2007(1) & 708.60 & 1343.80 & 1697.70 & 2946.60 \\
\hline & $C-2007 / 2008 a^{(1)}$ & 740.70 & 1437.20 & 1848.50 & 3140.50 \\
\hline & $C-2007 / 2008 b^{(1)}$ & 535.70 & 1142.10 & 1588.70 & 2949.50 \\
\hline & P-2007/2008(2) & 886.60 & 1242.20 & 1758.30 & 3515.20 \\
\hline \multirow{4}{*}{ Accumulated precipitation (mm) } & C-2006/2007(1) & 124.40 & 263.40 & 289.40 & 663.00 \\
\hline & $C-2007 / 2008 a^{(1)}$ & 172.10 & 388.20 & 473.90 & 749.50 \\
\hline & $C-2007 / 2008 b^{(1)}$ & 163.80 & 361.20 & 467.90 & 707.50 \\
\hline & P-2007/2008(2) & 184.80 & 185.60 & 379.20 & 760.40 \\
\hline
\end{tabular}

(1) Harvests in Castro; (2) Harvests in Ponta Grossa. 
Table 3. Averages of the calibrated parameters in the harvests: "Castro 2006/2007", "Castro 2007/2008a" and

"Ponta Grossa 2007/2008", for six models to estimate dry biomass productivity at the end of each soybean and maize crops stage, Campos Gerais region, with the input variables: days after planting (DAP); accumulated degree days (GDD); accumulated incident solar radiation (Rs); and, accumulated precipitation (P).

\begin{tabular}{|c|c|c|c|c|c|}
\hline Model & Parameter $^{(1)}$ & DAP-(days) & $\mathrm{GDD}_{-}^{-}\left({ }^{\circ} \mathrm{C}\right)$ & $\operatorname{Rs}\left(\mathrm{MJ} \mathrm{m}^{-2}\right.$ day $\left.^{-1}\right)$ & $\mathrm{P}(\mathrm{mm})$ \\
\hline \multicolumn{6}{|c|}{ Soybean } \\
\hline \multirow{4}{*}{ Streibig } & a & 10028.1 & 10054.3 & 10178 & 10494.8 \\
\hline & $\mathrm{b}$ & -5.50 & -5.42 & -5.08 & -4.32 \\
\hline & c & 70.25 & 644.21 & 1494.96 & 335.23 \\
\hline & $\mathrm{r}$ & 1.0 & 1.0 & 1.0 & 1.0 \\
\hline \multirow{4}{*}{ Gompertz \& Philos } & $\mathrm{a}$ & 10025.7 & 10058.1 & 10178.3 & 10410.2 \\
\hline & $\mathrm{b}$ & 25.07 & 23.54 & 19.77 & 14.61 \\
\hline & $\mathrm{c}$ & 0.05 & 0.01 & 0.00 & 0.01 \\
\hline & $\mathrm{r}$ & 1.0 & 1.0 & 1.0 & 1.0 \\
\hline \multirow{4}{*}{ Ratkowsky } & $\mathrm{a}$ & 9815.93 & 9818.6 & 9830.7 & 9873.1 \\
\hline & $\mathrm{b}$ & 1141.59 & 908.51 & 662.19 & 442.67 \\
\hline & c & 0.10 & 0.01 & 0.00 & 0.02 \\
\hline & $\mathrm{r}$ & 1.0 & 1.0 & 1.0 & 1.0 \\
\hline \multirow{4}{*}{ Brody } & $\mathrm{a}$ & 16785.6 & 20935.6 & 25726.8 & 136053 \\
\hline & $\mathrm{b}$ & 1.40 & 1.37 & 1.38 & 1.23 \\
\hline & c & 0.01 & 0.00 & 0.00 & 0.00 \\
\hline & $\mathrm{r}$ & 0.99 & 0.99 & 0.99 & 0.99 \\
\hline \multirow{4}{*}{ Bertalanffy } & $\mathrm{a}$ & 10220.9 & 10290.1 & 10562.1 & 10650.9 \\
\hline & $\mathrm{b}$ & 4.63 & 4.47 & 2.64 & 4.78 \\
\hline & $\mathrm{c}$ & 0.05 & 0.00 & 0.00 & 0.01 \\
\hline & $\mathrm{r}$ & 1.0 & 1.0 & 1.0 & 0.99 \\
\hline \multirow{4}{*}{ García y García } & $\mathrm{a}$ & 14049.4 & 13690.9 & 12563 & 11402.3 \\
\hline & $\mathrm{b}$ & 2.56 & 2.52 & 2.38 & 2.04 \\
\hline & $\mathrm{c}$ & 114.39 & 1052.26 & 2398.15 & 533.64 \\
\hline & $\mathrm{r}$ & 1.0 & 1.0 & 1.0 & 1.0 \\
\hline \multicolumn{6}{|c|}{ Maize } \\
\hline \multirow{4}{*}{ Streibig } & $\mathrm{a}$ & 14471.6 & 14535.5 & 14781.4 & 15885.9 \\
\hline & $\mathrm{b}$ & -28.16 & -18.39 & -21.15 & -48.44 \\
\hline & c & 83.13 & 893.54 & 1661.94 & 388.98 \\
\hline & $\mathrm{r}$ & 0.98 & 0.98 & 0.98 & 0.96 \\
\hline \multirow{4}{*}{ Gompertz \& Philos } & $\mathrm{a}$ & 14375.4 & 14436.9 & 14630.7 & 14161.4 \\
\hline & b & 53.01 & 49.47 & 47.46 & 253.64 \\
\hline & c & 0.05 & 0.00 & 0.00 & 0.02 \\
\hline & $\mathrm{r}$ & 0.95 & 0.96 & 0.95 & 0.93 \\
\hline \multirow{4}{*}{ Ratkowsky } & $\mathrm{a}$ & 14116.8 & 14074.9 & 14110.3 & 14134 \\
\hline & $\mathrm{b}$ & 460.54 & 364.37 & 281.11 & 581.25 \\
\hline & $\mathrm{c}$ & 0.18 & 0.01 & 0.00 & 0.02 \\
\hline & $\mathrm{r}$ & 0.92 & 0.95 & 0.95 & 0.93 \\
\hline \multirow{4}{*}{ Brody } & $\mathrm{a}$ & 20525.4 & 20563.2 & 33797.6 & 235938 \\
\hline & b & 2.2 & 2.06 & 1.76 & 1.88 \\
\hline & c & 0.02 & 0.00 & 0.00 & 0.00 \\
\hline & $\mathrm{r}$ & 0.93 & 0.93 & 0.93 & 0.91 \\
\hline \multirow{4}{*}{ Bertalanffy } & $\mathrm{a}$ & 14639.7 & 14717.9 & 15121.3 & 15190 \\
\hline & b & 8.43 & 6.77 & 5.64 & 3.97 \\
\hline & c & 0.05 & 0.00 & 0.00 & 0.01 \\
\hline & $\mathrm{r}$ & 0.95 & 0.95 & 0.95 & 0.92 \\
\hline \multirow{4}{*}{ García y García } & $\mathrm{a}$ & 20379.2 & 19811.2 & 18640.4 & 26669.1 \\
\hline & b & 3.60 & 3.06 & 3.33 & 3.52 \\
\hline & c & 134.22 & 1474.64 & 2661.9 & 577.58 \\
\hline & $\mathrm{r}$ & 1.0 & 1.0 & 1.0 & 0.96 \\
\hline
\end{tabular}

(1) Parameters of the equation - "a": kg ha-1; "b": dimensionless; "c": Streibig and García y García models have the same unit as the independent variable, and the others models have the inverse of the same unit as the independent variable. $r$ - Pearson correlation coefficient (dimensionless). 
showed higher values in the first collection stage. The "b" parameter values are linked to the shape of the model curves.

The "c" parameters of the Streibig and García y García models changed between the variables but were close between the soybean harvests (Table 3). The scale of each variable influences the "c" parameter.The Gompertz and Philos, Ratkowsky, Brody, and Bertalanffy models resulted in very minimal "c" parameters values, usually below 0.1 .

The Pearson correlation coefficient showed excellent results in all calibrated models, with significant variation (Table 3). Silva et al. (2014) tested Streibig model obtained excellent adjustments $(\mathrm{r} \geq 0.99)$ between dry weed biomass and the accumulated degree days (GDD). Understanding the production of dry biomass is essential to infer about the physiological processes of plant growth.

The tested soybean cultivar has as characteristic 129 days of the average total cycle. The shortest duration of the total cycle occurred in the "Ponta Grossa 2006/2007" harvest (127 days). However, it was the second among the four crops studied that had the highest dry biomass values at the end of the cycle. The result showed that the plants responded to other factors that are not necessarily related to the time that the crop remained in the field. As observed in the four analyzed harvests, the soybean crop cycle decreased as sowing was done later, as reported by Dallacort et al. (2006) and Kumagai and Takahashi (2020).

Several studies consider that logistic models are the ones that best adjust to the growth and dry matter accumulation by plants (Maia et al., 2009). Many are used to evaluate plant growth and development among the adjusted models, using time as a variable. However, there is little information in the literature about the use of models with the variables as accumulated degree days (GDD), accumulated incident solar radiation (Rs), and accumulated precipitation $(\mathrm{P})$.

The models' adjustment with the accumulated degree days (GDD) variable was adequate due to the thermal requirement being achieved in all the studied harvests. Grein et al. (2015) described for soybean, with $14^{\circ} \mathrm{C}$ of basal temperature, that the phenological cycle is completed with $1075^{\circ} \mathrm{C}$ GDD. The "Castro 2007/2008" harvest had the lowest accumulated degree days (GDD; $1104.30^{\circ} \mathrm{C}$ ), showing that the total accumulation of temperature in the cycle was not a limiting factor. However, the temperature influenced the crop cycle in the phenological stages.

As the rainfall variable is not well defined over the crop cycle and the experiment was not irrigated, the lack or excess of rain in a given season may be the cause that most influenced the models' adjustment. During the cycle of all evaluated soybean harvests, there was no water deficiency for long periods. The maximum interval without precipitation was 10 days in the "Castro 2006/2007" harvest; between 550 and $800 \mathrm{~mm}$ of water during the soybean cycle are necessary to obtain appropriate yields (EMBRAPA, 2013). In Table 2 , it was observed that the "Ponta Grossa 2006/2007" harvest (490.80 mm) was the only one with accumulated precipitation less than the recommended during the crop cycle. The highest accumulated precipitation occurred in the "Ponta Grossa 2007/2008" harvest (735.2 mm). Under irrigated conditions, Gomes et al. (2014) proposed a model able to predict soybean yield satisfactorily, showing that crops without water deficit resulted in less variability in productivity. Silva et al. (2018) calibrating and validating models to estimate soybean growth had limited productivity due to water stress.

The adjusted parameters for all models in the "Castro 2006/2007" maize harvest differed from the others (Table 3). The dry biomass between the full flowering and physiological maturation stages declined instead of increasing (Table 2). The unidentified problem may have occurred due to some variation or experimental error between the dry matter collection and determination. Therefore, significant adjustments for the "Castro 2006/2007" harvest would not be possible since the tested models consider that the plants' dry biomass only tends to increase and not to decrease.

As well as when adjusting the models' parameters for soybeans, the "a" parameters values of most models were close to the final dry biomass of maize crop (Table 3). In sigmoidal models, the "a" parameters indicate the maximum point reached by the dependent variable. In the Brody and García y García models, there was a high variation between the lowest and highest values. In the Brody model, the lowest and highest values were 3365.5 and $657640.5 \mathrm{~kg} \mathrm{ha}^{-1}$, and in the García y García model, the lowest and highest values were 10000.0 and $50000.0 \mathrm{~kg} \mathrm{ha}^{-1}$, respectively. In both models, the values occurred in the accumulated precipitation variable. The result indicated that high parameter variations make the models less efficient since the productivity estimate 
tends to become inaccurate. If precipitation is not well distributed throughout the crop cycle, long dry days may occur, causing a reduction in productivity. In addition, there was a requirement to condition parameters for some models and variables, restricting the maximum limits, since, in the unrestricted calibration process, the "a" parameters values became very high and inconsistent. The maximum limits imposed as a restriction were values slightly higher than the accumulated dry biomass in the final stage of each maize harvest.

The "b" parameter of the Streibig model remained the values close, except for the "Castro 2006/2007" maize harvest (Table 3). In the Gompertz model, the same occurred, but the parameter varied in the adjustment of the accumulated precipitation variable, with the lowest value being 19.16 and the highest 673.06. In the Ratkowsky model, the "b" values were higher than the others, presenting higher amplitude, with the lowest and highest value being 100.0 and 1543.7, respectively. There was also observed a restriction between the lowest and highest value of "b." However, the highest values still stood out in the "Castro 2006/2007" harvest.

In the Streibig and García y García models, the "c" parameters values changed between variables but were close between harvests. The scale of each variable is influenced by "c" values, and in the models Gompertz and Philos, Ratkowsky, Brody and Bertalanffy were very small, all below 0.1 .

Campos et al. (2012) obtained a great fit between the days after planting (DAP) variable and total dry biomass accumulation in three types of weed ( $r \geq 0.98)$. Except for the "Castro 2006/2007" maize harvest, the Pearson correlation coefficient obtained in the associations was narrow (Table 3). The lowest value was observed with the Ratkowsky model for maize crop, for the days after planting variable (DAP; $r=0.62$ ). The decay of dry biomass in the final crop stage made it difficult to obtain suitable adjustments.

The maize cultivars with an early growth cycle, such as the one used in the present experiment, have an average cycle between 120 and 130 days. The smallest cycle occurred in the "Castro 2006/2007" harvest (146 days; Table 2), according to the technical characteristics of the cultivar. For each maize phenological stage, caloric units are required for their development. As a result, high temperatures can accelerate the plant cycle due to the daily accumulation degree (Maldaner et al.,
2014). The results of the models' adjustment to the daily accumulated degree (GDD) for maize crops, were not satisfactory for the "Castro 2006/2007" harvest. For early cycle cultivars, it takes between 831 and 890 accumulated degree days to achieve pollination. In Table 2, it was observed in the full flowering stage that the lowest value of accumulated degree days was $878.75^{\circ} \mathrm{C}$, not being a factor that limited pollination.

The maize dry biomass production is directly related to solar radiation, converting it into chemical energy in photosynthesis. This process has importance in the plant physiological processes. In years with lower solar incidence and lower temperatures, there is a reduction in crop productivity (Maldaner et al., 2014).

For the maize crop to complete the cycle, between 500 and $800 \mathrm{~mm}$ of rain are needed (EMBRAPA, 2004). At the end of the crop cycle, the accumulated precipitation values were within this range (Table 2). During the cycle of all evaluated maize harvest, there was no water deficiency for extended time periods. The maximum interval without precipitation occurrence was 9 days in the "Castro 2006/2007" harvest.

The validation analysis was performed with the ranges of the parameters' values obtained in the calibration for each model and variable.For this purpose, harvests not used in the calibration process were considered. Even with suitable adjustments in the calibration, it was possible to verify that some harvest showed high absolute and relative errors. Table 4 shows the errors, coefficients, indexes, and performance obtained with the tested models in the associations between the observed and estimated dry biomass for the four soybean and maize phenological stages in the "Castro 2007/2008" and "Castro 2007/2008b" harvests, respectively.

For soybean, except for the models' performance for precipitation variable (Table 4), which was between "Terrible" and "Very good," the other variables showed promising performance between "Good" and "Excellent," with a predominance of "Excellent." In the individual adjustment, it was observed in the Brody and Bertalanffy models that the dry biomass values at the beginning of the crop cycle were negative for all tested variables (Figure 1). Therefore, the use of the Brody and Bertalanffy models was restricted to an specific interval.

Among all the models and variables analyzed for maize crop (Table 4), the Brody model obtained 
Table 4. Absolute (AE) and relative (RE) errors, Pearson correlation coefficient (r),

"d" and "c" indexes, and performance between the observed and estimated dry biomass with the analyzed models, for soybean (Castro 2007/2008 harvest) and maize (2007/2008 harvests) crops phenological stages.

\begin{tabular}{|c|c|c|c|c|c|c|c|}
\hline $\mathrm{Pa}$ & Variable & $\begin{array}{c}\mathrm{AE} \\
\left(\mathrm{kg} \mathrm{ha}^{-1}\right)\end{array}$ & $\operatorname{RE}(\%)$ & $\begin{array}{c}\mathrm{r} \\
\text { (dimensionless) }\end{array}$ & “d” & "c" & Performance \\
\hline \multicolumn{8}{|c|}{ Soybean crop (Castro 2007/2008 harvest) } \\
\hline Streibig & \multirow{6}{*}{ DAP } & 1142.6 & 24.6 & 1.00 & 0.95 & 0.95 & "Excellent" \\
\hline Gompertz and Philos & & 1170.8 & 25.2 & 1.00 & 0.95 & 0.95 & "Excellent" \\
\hline Ratkowsky & & 1035.1 & 22.8 & 1.00 & 0.96 & 0.96 & "Excellent" \\
\hline Brody & & 2039.3 & 36.4 & 0.97 & 0.88 & 0.86 & "Excellent" \\
\hline Bertalanffy & & 1292.0 & 27.6 & 1.00 & 0.95 & 0.95 & "Excellent" \\
\hline García y García & & 907.3 & 20.4 & 0.96 & 0.95 & 0.91 & "Excellent" \\
\hline Streibig & \multirow{6}{*}{ GDD } & 1055.5 & 29.4 & 0.96 & 0.96 & 0.93 & "Excellent" \\
\hline Gompertz \& Philos & & 1049.2 & 29.3 & 0.96 & 0.96 & 0.93 & "Excellent" \\
\hline Ratkowsky & & 1236.2 & 35.3 & 0.94 & 0.95 & 0.89 & "Excellent" \\
\hline Brody & & 1619.0 & 35.0 & 0.97 & 0.91 & 0.88 & "Excellent" \\
\hline Bertalanffy & & 1193.3 & 34.4 & 0.97 & 0.96 & 0.93 & "Excellent" \\
\hline García y García & & 2049.7 & 44.9 & 0.91 & 0.85 & 0.78 & "Very good" \\
\hline Streibig & \multirow{6}{*}{ Rs } & 865.1 & 19.8 & 0.99 & 0.97 & 0.96 & "Excellent" \\
\hline Gompertz \& Philos & & 1007.5 & 22.3 & 0.99 & 0.96 & 0.95 & "Excellent" \\
\hline Ratkowsky & & 849.5 & 19.3 & 0.99 & 0.96 & 0.96 & "Excellent" \\
\hline Brody & & 3993.2 & 52.9 & 0.97 & 0.73 & 0.71 & "Good" \\
\hline Bertalanffy & & 1001.8 & 22.5 & 0.99 & 0.96 & 0.95 & "Excellent" \\
\hline García y García & & 1357.6 & 27.7 & 0.99 & 0.92 & 0.91 & "Excellent" \\
\hline Streibig & \multirow{6}{*}{$\mathrm{P}$} & 3024.0 & 45.9 & 0.99 & 0.78 & 0.77 & "Very good" \\
\hline Gompertz \& Philos & & 3490.3 & 49.5 & 0.99 & 0.73 & 0.72 & "Good" \\
\hline Ratkowsky & & 2863.5 & 44.6 & 0.99 & 0.81 & 0.78 & "Very good" \\
\hline Brody & & 59810.4 & 94.4 & 0.97 & 0.11 & 0.10 & "Terrible" \\
\hline Bertalanffy & & 4820.6 & 57.5 & 0.96 & 0.61 & 0.59 & "Tolerable" \\
\hline García y García & & 3025.5 & 45.9 & 0.88 & 0.73 & 0.64 & "Medium" \\
\hline \multicolumn{8}{|c|}{ Maize crop (Castro 2007/2008b harvest) } \\
\hline Streibig & \multirow{6}{*}{ DAP } & 1075.6 & 18.0 & 0.98 & 0.98 & 0.95 & "Excellent" \\
\hline Gompertz \& Philos & & 839.3 & 14.2 & 0.99 & 0.99 & 0.98 & "Excellent" \\
\hline Ratkowsky & & 5846.6 & 46.7 & 0.70 & 0.60 & 0.42 & "Bad" \\
\hline Brody & & 2933.7 & 38.4 & 0.97 & 0.94 & 0.92 & "Excellent" \\
\hline Bertalanffy & & 3025.1 & 80.8 & 0.97 & 0.90 & 0.87 & "Excellent" \\
\hline García y García & & 1511.9 & 27.9 & 0.97 & 0.97 & 0.94 & "Excellent" \\
\hline Streibig & \multirow{6}{*}{ GDD } & 1301.1 & 23.3 & 0.98 & 0.97 & 0.95 & "Excellent" \\
\hline Gompertz \& Philos & & 857.5 & 14.6 & 0.99 & 0.99 & 0.98 & "Excellent" \\
\hline Ratkowsky & & 776.0 & 12.8 & 0.99 & 0.99 & 0.98 & "Excellent" \\
\hline Brody & & 2802.0 & 33.8 & 0.97 & 0.95 & 0.92 & "Excellent" \\
\hline Bertalanffy & & 1270.7 & 23.0 & 1.00 & 0.98 & 0.98 & "Excellent" \\
\hline García y García & & 1936.5 & 32.1 & 0.96 & 0.96 & 0.92 & "Excellent" \\
\hline Streibig & \multirow{6}{*}{ Rs } & 2285.5 & 48.4 & 0.93 & 0.93 & 0.87 & "Excellent" \\
\hline Gompertz \& Philos & & 1551.8 & 29.9 & 0.97 & 0.96 & 0.93 & "Excellent" \\
\hline Ratkowsky & & 1054.1 & 18.5 & 0.98 & 0.98 & 0.96 & "Excellent" \\
\hline Brody & & 7071.9 & 69.7 & 0.98 & 0.81 & 0.79 & "Very good" \\
\hline Bertalanffy & & 4732.3 & 228.5 & 0.95 & 0.80 & 0.76 & "Very good" \\
\hline García y García & & 2539.2 & 45.8 & 0.93 & 0.94 & 0.87 & "Excellent" \\
\hline Streibig & \multirow{6}{*}{$\mathrm{P}$} & 2937.8 & 36.5 & 0.92 & 0.91322 & 0.84 & "Very good" \\
\hline Gompertz \& Philos & & 808.9 & 11.1 & 0.99 & 0.99016 & 0.98 & "Excellent" \\
\hline Ratkowsky & & 996.1 & 13.0 & 0.98 & 0.98455 & 0.97 & "Excellent" \\
\hline Brody & & 123690.9 & 94.8 & 0.91 & 0.08558 & 0.08 & "Terrible" \\
\hline Bertalanffy & & 2793.3 & 29.7 & 0.89 & 0.89515 & 0.80 & "Very good" \\
\hline García y García & & 4301.5 & 39.3 & 0.89 & 0.82104 & 0.73 & "Good" \\
\hline
\end{tabular}




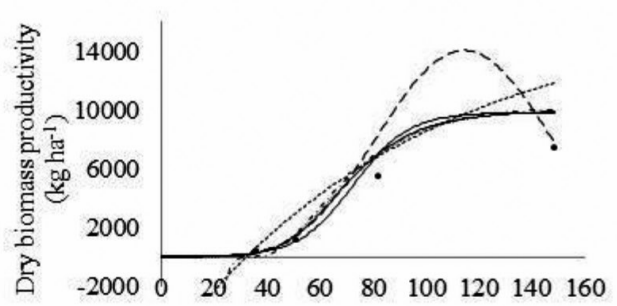

a1)

Days after planting (DAP; days)

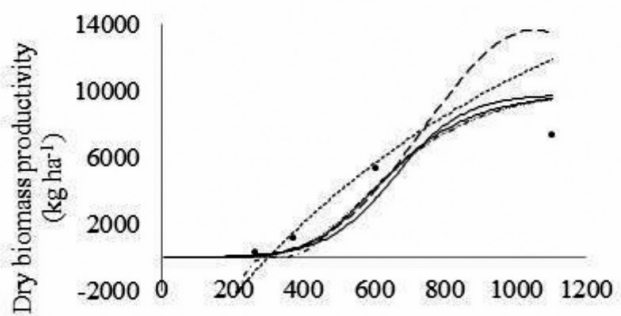

b1)

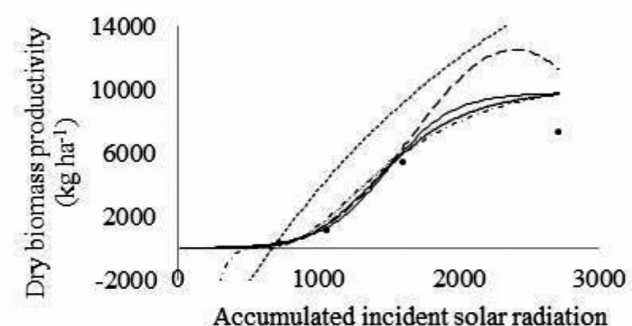

c1)

(Rs; $\mathrm{MJ} \mathrm{m}^{-2}$ day $^{-1}$ )

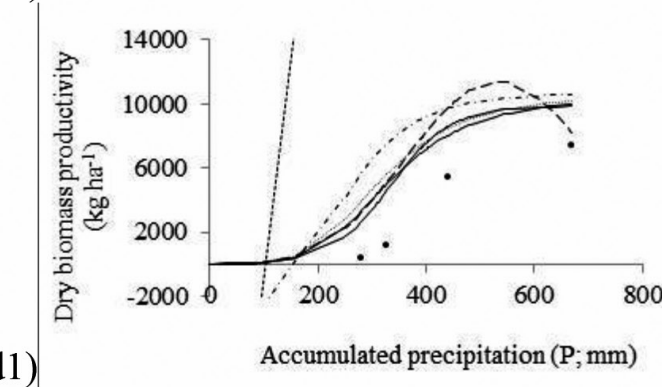

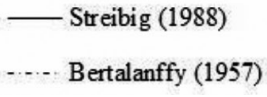

a2)

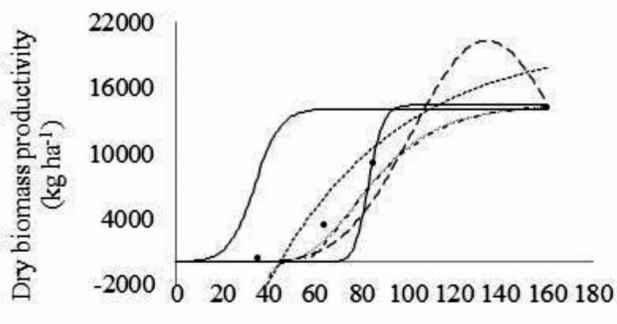

Days after planting (DAP; days)

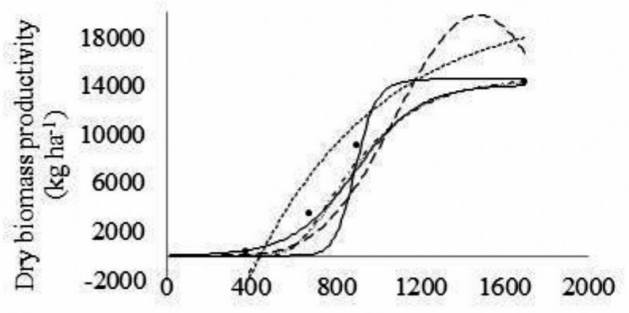

b2)

Accumulated degree days $\left(\mathrm{GDD} ; \mathrm{C}^{\circ}\right)$

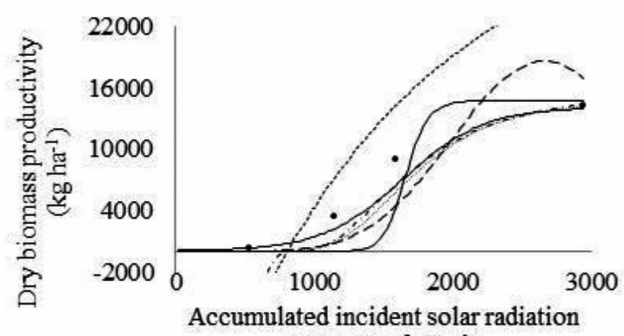

c2)

d2)

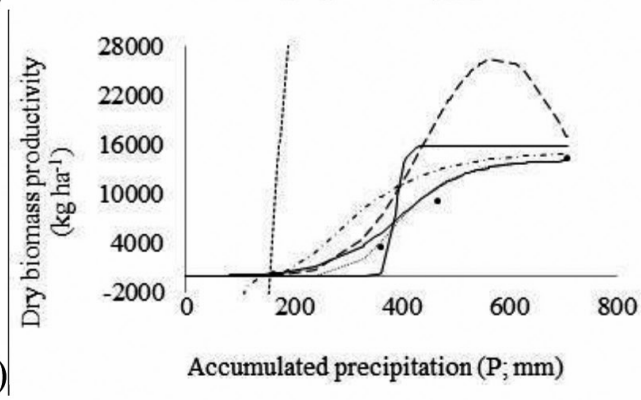

..... Gompertz \& Philos (1825)

— Ratkowsky (1983)

---. Garcia y Garcia (2002)

Figure 1 - Dry biomass productivity (kg ha-1) for soybean (1) and maize (2), observed in the field ("Castro 2007/2008" soybean harvest; "Castro 2007/2008b maize harvest) and estimated with six tested models, using the "a", "b" and "c" average parameters, obtained in the calibration process in the Campos Gerais region, Southern Brazil, for the input variables: a) Days after planting, b) Accumulated degree days, c) Accumulated incident solar radiation, d) Accumulated precipitation.

a "Terrible" performance for the precipitation variable, and the Ratkowsky model obtained a "Bad" performance for the days after planting variable. The other models performed between "Good" and "Very good." As occurred for soybean crop, in the individual adjustment of the models, it was also observed in the Brody and Bertalanffy models that the dry biomass values at the beginning of the crop cycle were negative for all the variables analyzed (Figure 1). The use of the Brody and Bertalanffy models should be restricted to an specific interval. 


\section{Conclusions}

Except for the accumulated growing degree days (GDD) variable, the soybean harvests that had the highest days after planting (DAP), incident solar radiation (Rs), and precipitation $(\mathrm{P})$ to reach the physiological maturation stage were not the ones that obtained the highest final dry biomass productivity. The soybean crop cycle decreased as sowing was performed at later dates in Campos Gerais. The association of dry biomass accumulation of the crops and variables tested was satisfactory in the calibration.
With the exception of the models' performance for precipitation variable (between "Terrible" and "Excellent") for soybean and maize, the other variables showed promising performances between "Bad" and "Excellent," with a predominance of "Excellent."

The occurrence of negative values of estimated dry biomass at the beginning of the harvests with Brody and Bertalanffy models indicated a restriction on their use. Even with suitable adjustments in the calibration for soybean and maize, the validation indicated high absolute and relative errors in the harvests.

\section{Literature Cited}

Álvares, C.A.; Stape, J.L.; Sentelhas, P.C.; Gonçalves, J.L.M.; Sparovek, G.

2013. Köppens's climate classification map for Brazil. Meteorologische Zeitschrift, 22 (6): 711-728.

Arnold, C.Y.

1959. The determination and significance of the base temperature in a linear heat unit system. Proceedings of the American Society for Horticultural Science, 74 (1): 430-445.

Bertalanffy, L.

1957. Quantitative laws in metabolism and growth. Quarterly Review of Biology, 32 (3): 217-230.

Brody, S.

1945. Bioenergetics and Growth. Reinhold Publishing Corp., New York. 1023 p.

Campos, L.H.F.; Mello, M.S.C.; Carvalho, S.J.P.; Nicolai, M.; Christoffoleti, P.J.

2012. Crescimento inicial de Merremia cissoides, Neonotonia wightii e Stizolobium aterrimum. Planta Daninha, 30 (3): 497-504.

Chukwujindu, N.S.

2017. A comprehensive review of empirical models for estimating global solar radiation in Africa. Renewable and Sustainable Energy Reviews, 78: 955-995.

Dallacort, R.; Freitas, P.S.L.; Faria, R.T.; Gonçalves, A.C.A.;

Rezende, R.; Bertonha, A.

2006. Utilização do modelo Cropgro-soybean na determinação de melhores épocas de semeadura da cultura da soja, na região de Palotina, Estado do Paraná. Acta Scientiarum Agronomy, 28 (4): 583-589.

EMBRAPA.

2004. Empresa Brasileira de Pesquisa Agropecuária (Brasília, DF). Manual de segurança e qualidade para a cultura do milho. EMBRAPA SEDE, Brasília, Brazil. 78 p.

EMBRAPA.

2013. Empresa Brasileira de Pesquisa Agropecuária (Londrina, PR). Tecnologias de produção de soja - Região Central do Brasil 2014. EMBRAPA SOJA. Londrina, Brazil. 266 p. García y García, A.

2020. Modelos para área foliar, fitomassa e extracáo de nutrientes na cultura de arroz. Superior de Agricultura
Luiz de Queiroz. Universidade de Sáo Paulo, Piracicaba, Sáo Paulo, Brazil. 112 p.

Gomes, A.C.S.; Robaina, A.D.; Peiter, M.X.; Soares, F.C.; Parizi, A.R.C.

2014. Modelo para estimativa da produtividade para a cultura da soja. Ciência Rural, 44 (1): 43-49.

Gompertz, B.; Philos, T.

1825. On the nature of the function expressive of the law of human mortality, and on a new mode of determining the value of life contingencies. Philosophical Transactions of the Royal Society of London, 115 (1825): 513-585.

Grein, M.A.; Neves, L.O.; Ieler, J.; Melo, L.C.; Gutz, T.

2015. Necessidade térmica para a cultura da soja para o Alto Vale do Itajaí - SC. In: $8^{a}$ Mostra Nacional de Iniciação Científica e Tecnológica Interdisciplinar, Santa Rosa do Sul, Brazil.

INMET.

2009. Instituto Nacional de Meteorologia (Brasília, DF). Agrometeorologia dos cultivos: o fator meteorológico na produção agrícola/organizador José Eduardo B. A Monteiro. Brasília, Brazil. 530 p.

Jones, J.W.; Antle, J.M.; Basso, B.; Boote, K.J.; Conant, R.T.; Foster, I.; Godfray, H.C.J.; Herrero, M.; Howitt, R.E.; Janssen, S.; Keating, B.A.; Munoz-Carpena, R.; Porter, C.H.; Rosenzweig, C.; Wheelerk, T.R.

2017. Brief history of agricultural systems modeling. Agricultural Systems, 155, 240-254.

Kumagai, E.; Takahashi, T.

2020. Soybean (Glycine max (L.) Merr.) Yield reduction due to late sowing as a function of radiation interception and use in a cool region of Northern Japan. Agronomy, 10 (66): $1-14$

Maia, E.; Siqueira, D.L.; Silva, F.F.; Peternelli, L.A.; Salomão, L.C.C.

2009. Método de comparação de modelos de regressão nãolineares em bananeiras. Ciência Rural, 39 (5): 1380-1386.

Maldaner, L.J.; Horing, K.; Schneider, J.F.; Frigo, J.P.; Azevedo, K.D. de; Grzesiuck, A.E.

2014. Exigência agroclimática da cultura do milho (Zea mays). Revista Brasileira de Energias Renováveis, 3, 13-23. 
Moebius-Clune, B.N.; Van Es, H.M.; Idowu, O.J.; Schindelbeck, R.R.; Moebius-Clune, D.J.; Wolfe, D.W.; Abawi, G.S.; Thies, J.E.; Gugino, B.K.; Lucey, R.

2008. Long-term effects of harvesting maize stover and tillage on soil quality. Soil Science Society of America Journal, 72 (4): 960-969.

Palencia, P.; Martínez, F.; Medina, J.J.; López-Medina, J.

2013. Strawberry yield efficiency and its correlation with temperature and solar radiation. Horticultura Brasileira, 31 (1): 93-99.

Ratkowsky, D.A.

1983. Nonlinear regression modeling: a unified practical approach. Marcel Dekker, New York.

Sánchez, B.; Rasmussen, A.; Porter, J.R.

2014. Temperatures and the growth and development of maize and rice: a review. Global Change Biology, 20, 408-17.

Silva, A.P.P.; Marques, B.S.; Lima, R.S.O.; Machado, E.C.R.;

Gonçalves, M.F.; Carvalho, S.J.P.

2014. Crescimento e desenvolvimento de plantas daninhas com base em dias ou unidades térmicas. Planta Daninha, 32 (1): 81-89.

Silva, V.P.R.; Silva, R.A.E; Maciel, G.F.; Braga, C.C.; Silva Júnior, J.L.C.; Souza, E.P.; Almeida, R.S.R.; Silva, M.T.; Holanda, R.M.
2018. Calibration and validation of the AquaCrop model for the soybean crop grown under different levels of irrigation in the Matopiba region, Brazil. Ciência Rural, 48 (1): $1-8$.

Souza, J.L.M.

2018. Fundamentos de matemática e estatística para formulação de modelos e análise de dados: aplicado às ciências agrárias. Curitiba: Plataforma Moretti/DSEA/ SCA/UFPR. (Série Didática).

Souza, P.J.O.P.; Abreu, J.P.M.M.; Rocha, E.J.P.; Ribeiro, A.

2010. Exigência térmica da soja nas condições climáticas da Amazônia. In: XVI CBMET - Congresso Brasileiro de Meteorologia. Anais - Agrometeorologia, Micrometeorologia e Hidrometeorologia.

Streibig, J.C.

1988. Herbicide bioassay. Weed Research, 28 (6): 479-484. Xu, Q.; Peng, W.; Ling, C.

2020. An experimental analysis of soybean straw combustion on both $\mathrm{CO}$ and $\mathrm{NO}_{\mathrm{x}}$ emission characteristics in a tubular furnace. Energies, 13 (7): 1-12.

Wazilewski, W.T.; Santos, R.F.; Bassegio, D.

2011. Exigência térmica da cultura da soja para a região de Cascavel - Paraná. Revista Cultivando o Saber, 4 (3): 130-139. 